\title{
Research on the Control Model of the Sub-Branch Corporations' Total Remunerations
}

\author{
Yiguo Jiang \\ HR Dept. \\ China Electric Power Research Institute \\ Beijing, China \\ 770640153@qq.com
}

\author{
Xuan Zou \\ College of Economics and Management \\ North China Electric Power University \\ Beijing, China \\ zouxuan0728@163.com
}

\begin{abstract}
Control and management of sub-branches' total remunerations is always a great problem. The way to control the total remunerations within a reasonable range without affecting the employees' enthusiasm and the way to reduce the labor cost while attracting talented people always confused the HR department and even the executives. From a macroscopic view of input-output analysis, this article declared a modified way to control the sub-branches' total remunerations. This model was built based on benefit indicators, calculation methods, classification scheme, etc. Its goal is to solve the problem of the balance between the incentive and constraints in sub-branches, and to achieve an efficient way to control and manage the sub-branches' total remunerations.
\end{abstract}

Keywords- sub-branch; total remunerations; control model

\section{INTRODUCTION}

Controlling the total remunerations of the sub-branches is always a game played between the corporation and its subbranches. Every executive of the sub-branches is more willing to fight for the maximum total remunerations of his own company to exchange the support of his subordinates. Furthermore, he would rather drive down his own annual salary than completely carry out the policies of downsizing for efficiency and bringing down the labor cost.

However, in the modern age of network economy and information, managing the total remunerations efficiently is not only meaningful to control the labor costs of the subbranches, but also helpful to encourage them to optimize the personnel structure and improve their efficiency.

\section{CHOOSING THE SCHEME OF THE TOTAL REMUNERATIONS CONSTRUCTION}

Several widely used calculation methods of the total remunerations are stated below:

a) Full Association Method

Total remunerations $=$ Indicator $\mathrm{A} \times$ Coefficient $1+$ Indicator $\mathrm{B} \times$ Coefficient $2+\ldots \ldots+$ Indicator $\mathrm{Z} \times$ Coefficient $\mathrm{N}$.

b) Cardinal number + Increments

Total remunerations $=$ Cardinal part $\mathrm{a}+$ Increment part $\mathrm{b}$ $=$ Cardinal part $\mathrm{a}+$ (Indicator $1 \times$ Coefficient $1+\ldots \ldots+$ Indicator $\mathrm{N} \times$ Coefficient $\mathrm{N}$ ).

c) Approved Growth Rate Method

Total remunerations $=$ Total remunerations of last year $\times$ $(1+$ Growth Rate)

\section{d) Hierarchical Division Method}

The total remunerations can be concluded by multiplying staff numbers of three kinds of remunerations levels, which are the top, the middle and the largest group.

By comparing the advantages and disadvantages of the methods above, this paper combined "Cardinal number + Increments" and "Approved Growth Rate Method" to construct a modified control management scheme of the total remunerations. The annual total remunerations are composed of the predicting cardinal number, the performance remunerations provision and the profit-sharing part. The calculating formula is:

Annual Total Remunerations

$=($ Radix Number of the Total Remunerations + Current Year's Provision Performance Remunerations) $\times$ A + Profitsharing Part.

$\mathrm{A}$ is the integrate accommodation coefficient of the total remunerations.

This method can overcome the shortcomings of the two methods above, as it not only guarantees the stability and security function of remunerations, but also strengthens the motivation effect and guiding quality, while the cardinal number of the total remunerations shows a link to the actual profit. Besides, it also has advantages like being open to public, easy to be understood, reflecting the relative contribution and difference among branches and subsidiaries, improving competitiveness and the internal equity and so on.

\section{DESIGNING THE CONTROL MANAGEMENT MODEL OF THE TOTAL REMUNERATIONS}

We illustrate every part of the model with an example of the control and management of sub-branches in a network corporation Y.

\section{A. Identification of the Predicting Radix Number of the Total Remunerations}

It can be identified mainly based on the total remunerations issued last year and an overall consideration of the characteristics of the sub-branches' life cycle, which should make a distinction between net increases of staff in growth-type enterprises and net decreases of staff in decline. Meanwhile, take the onetime increase of the total remunerations which caused by irresistible factors into account and deduct them. Due to the rigidity of the remunerations, if there are no special cases, the level of the 
predicting cardinal number should not be lower than that in last year.

\section{B. Construction of the Indicator System of the Performance Remunerations}

The performance remunerations provision of the current year depends on the appraisal results of every branch through the indicators linked to the performance remunerations. Therefore, identifying the indicators system of the performance remunerations is the key to the whole model design. Several problems need to be solved:

\section{1) Determination of the Linked Indicators}

The linked indicators of benefit remunerations must be developed based on the conglomerate's strategy, or the control of total remunerations cannot be achieved. The types of indicators include:

a) Economic Benefit Indicators, such as income and profit, which are important indicators for evaluating and appraising the profitability of the business, but also are the indicators indirectly reflecting the performance of the employees of the branches and subsidiaries. This indicator is suitable as the major linked indicator.

b) HRM Benefit Indicators, which are the ones that reveal the association of HRM such as the labor efficiency of the companies and personnel structure, as per capita contribution rate, which reflects the level of input and output efficiency of labor of the subsidiaries. Thus, it can guide their companies to improve labor efficiency and the input and output levels of labor costs, continuing to optimize the relationship between the internal staff structure and salary distribution.

c) Adjustment Indicators, considering the respective industry, type of business, business cycle and the level of the CPI and per capita income of the branches and subsidiaries to adjust the control objectives and total number in time according to changes in the external environment, which make sure reflecting the protection functions of the remunerations.

Therefore, the author chose as following four categories of indicators combined to establish effective index system (as Figure 2).

2) Determination of the target value of index

Top-down decomposition of $\mathrm{Y}$ Conglomerate's total economic goals, the standards of the main business income, profits and other indicators should be determined by the conglomerate and the subsidiary in consultation, which also formed a game between each other. Since the target completion rate is based on the comparison between the target value and the complete value, using excess progressive manner, i.e. the more complete value, the more incentive, thus the branches intend to reduce the target value in such a case.

To correct information asymmetry and effectively stimulate the enthusiasm of the subsidiaries, Conglomerate

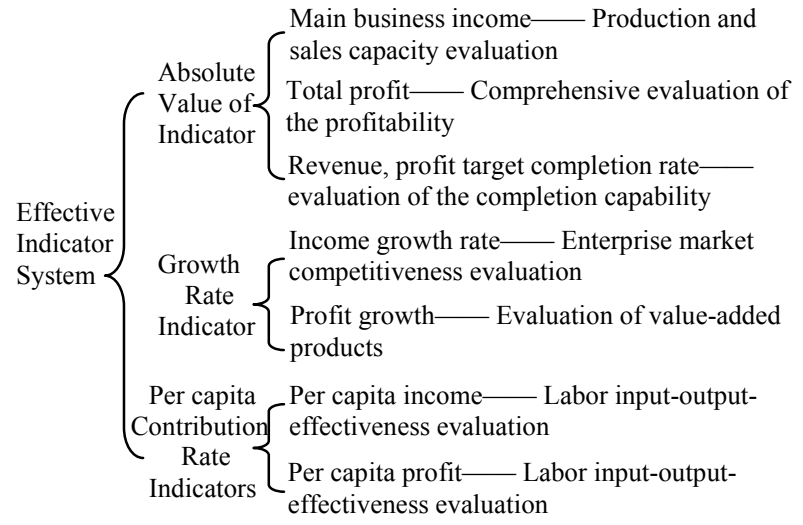

Figure 1. Indicators linked to the benefit remunerations of Y-owned subsidiaries.

Y's appraisal also takes into account the increase factor, the gap between the target value and the prior year completion value, and the relative increase between each subsidiary coefficient of horizontal comparison (shown below).

Determining the indicator target value is based on last year's actual completion, to ensure that the relative stability and continuity of the target value, growth relative coefficient makes the subsidiaries to repeatedly weigh, only combining their operational capacity and the actual identification of the target value is the most reasonable and most effective.

3) Calculation methods of benefit composite index

Benefit Composite Index $=\sum_{i=1}^{n}\left[\left(\mathrm{C}_{\mathrm{i}}+\mathrm{P}_{\mathrm{i}}+\mathrm{G}_{\mathrm{i}}\right) \times \mathrm{L}_{\mathrm{i}}\right]$

$C_{i}$ is relative coefficient of completion rate. $P_{i}$ is relative coefficient of per capita contribution. $G_{i}$ is relative coefficient of increment. $\mathrm{L}_{\mathrm{i}}$ is linked coefficient.

$\mathrm{C}_{\mathrm{i}}=$ index completion rate/maximum completion rate $\times 100$ $=$ (completion value $/$ target value $) /$ maximum completion rate $\times 100$

$\mathrm{P}_{\mathrm{i}}=$ per capita contribution rate / maximum per capita contribution rate $\times 100=($ completion value $/$ number of employees) / maximum completion rate $\times 100$

$\mathrm{G}_{\mathrm{i}}=$ amount of own growth / maximum increment $\times 100=$ (the target value of next year - completion value of this year) $/$ maximum increment $\times 100$.

The benefit composite index calculated completion rate of the main considerations linked to indicators, per capita contribution rate increase to the relative coefficient substituted into the formula. The relative coefficients from each sub-branch data accounted for the horizontal maximum ratio, not only consider the performance completion of each unit, but also compared to each other through an internal sort to further strengthen the incentive effect. 
The table shown below is about 8 sub-branches belong to $\mathrm{Y}$ Conglomerate, selecting the main business income and total profit to calculate the benefit index in the following Table I and II :

TABLE I. THE MAIN BUSINESS INCOME INDEX TABLE OF Y CONGLOMERATE SUB-BRANCHES

\begin{tabular}{c|c|c|c|c|c|c|c|c}
\hline & \multirow{2}{*}{$\begin{array}{c}\text { Number } \\
\text { of } \\
\text {-any } \\
\text { Name }\end{array}$} & \multicolumn{6}{|c}{ Main Business Income (Ten Thousand) } \\
\cline { 5 - 9 } & $\begin{array}{c}\text { Ees in } \\
2012\end{array}$ & $\begin{array}{c}\text { Target } \\
\text { value } \\
\text { of } \\
2012\end{array}$ & $\begin{array}{c}\text { Comple } \\
\text {-tion } \\
\text { value }\end{array}$ & $\boldsymbol{C}_{1}$ & $\begin{array}{c}\text { Per } \\
\text { capita } \\
\text { contri- } \\
\text { bution } \\
\text { rate }\end{array}$ & $\boldsymbol{P}_{1}$ & $\begin{array}{c}\text { Target } \\
\text { value } \\
\text { of } \\
2013\end{array}$ & $\boldsymbol{G}_{1}$ \\
\hline YT & 258 & 45000 & 48412.9 & 66.36 & 187.6 & 36.2 & 100000 & 100 \\
\hline STA & 464 & 40000 & 56360.2 & 86.91 & 121.4 & 23.4 & 60000 & 7.06 \\
\hline BHG & 336 & 25000 & 31907.3 & 78.73 & 94.96 & 18.3 & 39386 & 14.5 \\
\hline GN & 196 & 22000 & 22240.0 & 62.36 & 113.4 & 21.8 & 23352 & 2.16 \\
\hline CTN & 164 & 85000 & 85111.5 & 61.76 & 518.9 & 100 & 100000 & 28.8 \\
\hline FDD & 162 & 45000 & 46762.0 & 64.10 & 288.6 & 55.6 & 68000 & 41.2 \\
\hline BLU & 137 & 12500 & 20264.7 & 100 & 147.9 & 28.5 & 22000 & 3.36 \\
\hline ROL & 48 & 1910 & 1674.0 & 54.06 & 34.88 & 6.72 & 1757.7 & 0.16 \\
\hline
\end{tabular}

TABLE II. THE PROFITS INDEX TABLE OF Y CONGLOMERATE SUBBRANCHES

\begin{tabular}{c|c|c|c|c|c|c|c|c}
\hline \multirow{2}{*}{$\begin{array}{c}\text { Comp } \\
\text {-any }\end{array}$} & $\begin{array}{c}\text { Number } \\
\text { of } \\
\text { Employ } \\
\text {-ees in } \\
2012\end{array}$ & $\begin{array}{c}\text { Target } \\
\text { value } \\
\text { of } \\
2012\end{array}$ & $\begin{array}{c}\text { Comple } \\
\text {-tion } \\
\text { value }\end{array}$ & $\boldsymbol{C}_{2}$ & $\begin{array}{c}\text { Per } \\
\text { capita } \\
\text { contri- } \\
\text { bution } \\
\text { rate }\end{array}$ & $\boldsymbol{P}_{2}$ & $\begin{array}{c}\text { Target } \\
\text { value } \\
\text { of } \\
2013\end{array}$ & $\boldsymbol{G}_{2}$ \\
\hline YT & 258 & 4000 & 4070.0 & 50.88 & 15.78 & 32.3 & 8000 & 100 \\
\hline STA & 464 & 4000 & 4793.7 & 59.92 & 10.33 & 21.1 & 7500 & 68.8 \\
\hline BHG & 336 & 5000 & 5855.0 & 58.55 & 17.43 & 35.7 & 7409 & 39.5 \\
\hline GN & 196 & 1100 & 1107.0 & 50.32 & 5.65 & 11.5 & 1162.3 & 1.41 \\
\hline CTN & 164 & 4000 & 8000.0 & 100 & 48.78 & 100. & 7000 & 25.4 \\
\hline FDD & 162 & 1353 & 1422.0 & 52.55 & 8.78 & 17.9 & 1648 & 5.75 \\
\hline BLU & 137 & 800 & 896.2 & 56.01 & 6.54 & 13.4 & 1600 & 17.9 \\
\hline ROL & 48 & 280 & 287.0 & 51.25 & 5.98 & 12.2 & 301.35 & 0.37 \\
\hline
\end{tabular}

4) Calculation of the Sub-branch's Classifications

According to efficiency composite index formula, calculate efficiency composite index of 8 Sub-branches belonging to $\mathrm{Y}$ accounting for $50 \%$ of income and profit indicator and classify the companies (as Table III).

This classification combines the level of effectiveness of the units, per capita input-output efficiency and relatively internal efficiency, which can effectively avoid unfairness caused by extrinsic such as asset size among the branches. Using quantitative methods can reduce the sub-branches for bargaining, not only to ensure the strength and fairness of the incentive, but also strive to promote within the conglomerate.

As the benefit composite index to adjust, to raise the total remunerations not simply by increasing the amount of labors, should increase economic efficiency, especially the increase in per capita economic performance.
TABLE III. ClasSIFICATION CALCULATION TABLE OF Y CONGLOMERATE SUB-BRANCHES

\begin{tabular}{|c|c|c|c|}
\hline $\begin{array}{l}\text { Company } \\
\text { categories }\end{array}$ & Score range & $\begin{array}{c}\text { Company } \\
\text { name }\end{array}$ & $\begin{array}{c}\text { Benefit } \\
\text { composite } \\
\text { index }\end{array}$ \\
\hline \multirow{2}{*}{ A class Company } & \multirow{2}{*}{$X>150$} & YT & 192.87 \\
\hline & & $\mathrm{CTN}$ & 182.59 \\
\hline \multirow{2}{*}{ B class Company } & \multirow{2}{*}{$150 \geq X>120$} & STA & 133.67 \\
\hline & & BHG & 122.67 \\
\hline \multirow{2}{*}{ C class Company } & \multirow{2}{*}{$120 \geq X>90$} & FDD & 118.59 \\
\hline & & BLU & 109.60 \\
\hline D class Company & $90 \geqslant x>70$ & GN & 74.84 \\
\hline E class Company & $x \leqslant 70$ & ROL & 62.41 \\
\hline
\end{tabular}

TABLE IV. ACCOUNT OF THE CURRENT YEAR PERFORMANCE REMUNERATIONS

\begin{tabular}{c|c|c}
\hline $\begin{array}{c}\text { Company } \\
\text { Categories }\end{array}$ & $\begin{array}{c}\text { Adjustment of Radix } \\
\text { Number }\end{array}$ & $\begin{array}{c}\text { Performance } \\
\text { Remunerations }\end{array}$ \\
\hline A & Unchanged & $\begin{array}{c}\text { Radix Number } \times[0.25+(\mathrm{X}- \\
\mathrm{S} 1) /(\mathrm{S}-\mathrm{S} 1) \times 0.1]\end{array}$ \\
\hline B & Unchanged & $\begin{array}{c}\text { Radix Number } \times[0.25 \times(\mathrm{X}- \\
\mathrm{S} 1) /(\mathrm{S}-\mathrm{S} 1)]\end{array}$ \\
\hline C & Unchanged & Radix Number $\times 100 \%$ \\
\hline D & Radix Number $\times \mathrm{X} / 100 \times$ & 0 \\
\hline E & Radix Number $\times 80 \%$ & 0 \\
\hline $\mathrm{X}$ is benefit composite index. S1 is the minimum value of each grade interval. S is maximum value
\end{tabular}
of each grade interval

\section{Account of the current year accrued benefit total remunerations}

The current year's provision performance remunerations approved and extracted based on the results of the categories of each sub-branches (Table IV).

\section{Profit sharing}

If Sub-branch completes the value of annual benefit index, and the comprehensive evaluation is $\mathrm{A}$, the excess profit target accounting can be shared by its employees, excluding operations managers. Profit sharing inspire the sub-branch's employees to keep their own performance goals in pace with the objectives of the company to enhance the overall personal and organizational effectiveness, besides can attract and retain good employees.

\section{OPERATION PROPOSAL BASED ON THE MODIFIED CONTROL MODEL}

\section{a) Changing concepts}

We should change our focus point from the traditional cost control, which is applicable to individual companies, to returns on investment. When the branch companies need to add personnel and increase total remunerations, the conglomerate's revenue and profit evaluation criterions should be improved at the same time. This will prompt the 
business units to consider if their input-output efficiency and personnel increase returns can meet the performance evaluation criterions of the conglomerate.

b) Establishment of the total remunerations management system that matches the conglomerate's management and control model

Since we have multiple business units, there must be some competitions between them. Therefore, how to solve the internal fairness becomes a particularly prominent problem.

Firstly, scientifically determine of the sub-branch corporation's evaluation indicator system. We should not ignore our original intention of total remunerations management which is its guiding function. What's more, establishment of a scientific index standard and calculation method. We can improve the calculation method to guide them focus on the improvement of efficiency and competitive position within the conglomerate.

c) Standardization of the whole remunerations management process

Firstly, organize every unit to budget the total remunerations in advance. Secondly, adjust the remunerations budget in time in the implementation, monitoring the whole implementation process and conduct periodic analysis. Thirdly, perform a liquidation evaluation on the implementations of the total remunerations budget. Through the management and control of the whole process, we can play the supporting and protection functions of total remunerations and strengthen the constrained control mechanism.

d) Establishment of the internal and external balance comparison mechanism

Based on the benchmarking management, it is necessary and effective to build a balance comparison mechanism between competitors and the affiliated companies, such as the comparison with similar enterprises at home and abroad, the comparison between the units within the conglomerate, and time-based longitudinal comparison.

\section{CONCLUSION}

In the management and control of the total remunerations, the most important thing is to solve the problem of balance between the incentives and constraints in the sub-branch corporations. From the perspective of the whole conglomerate to management and control, not only the perspective of cost control should be the fundamental way to solve this problem.

This article designs an effective model of the total remunerations control in the sub-branch corporations systematically from the angle of input and output. Different from the former control method, which focused on the stations and capacity in the micro level, the new one can not only control the labor costs in sub-branch companies effectively, but also ensure the horizontal equity between sub-braches and the incentive effect, leading their innovations and efforts in the improvement of economic performance, especially the artificial efficiency.

\section{REFERENCES}

[1] Guocheng Zhu, "The real total remuneration analysis and control strategy," China: Human Resource Management, Aug. 2009, pp. 5052.

[2] Hailong Huang, "Strategic adjustment and control of the total compensation," China: HR Managers, Nov. 2009, pp. 33-36.

[3] Guocheng Zhu, "Total remuneration's cycle management," China: Human Resource, Feb. 2011, pp. 19-21.

[4] Wei Li, "Effective management of the Group total remuneration," China: Modern Business, 2008, pp. 79.

[5] Hao Tan, "Management of total remuneration within group company," China: Human Resource Development, Feb. 2006, pp. 4142. 